\title{
Modulating Hypoxia-Inducible Transcription by Disrupting the HIF-1-DNA Interface
}

\author{
Nicholas G. Nickols, Claire S. Jacobs, Michelle E. Farkas, and Peter B. Dervan ${ }^{\star}$ \\ Division of Chemistry and Chemical Engineering, California Institute of Technology, Pasadena, \\ California 91125
}

\section{Abstract}

Transcription mediated by hypoxia-inducible factor (HIF-1) contributes to tumor angiogenesis and metastasis but is also involved in activation of cell-death pathways and normal physiological processes. Given the complexity of HIF-1 signaling, it could be advantageous to target a subset of HIF-1 effectors rather than the entire pathway. We compare the genome-wide effects of three molecules that each interfere with the HIF-1-DNA interaction: a polyamide targeted to the hypoxia response element, small interfering RNA targeted to HIF- $1 \alpha$, and echinomycin, a DNAbinding natural product with a similar but less specific sequence preference than the polyamide. The polyamide affects a subset of hypoxia-induced genes consistent with its binding site preferences. For comparison, HIF-1 $\alpha$ siRNA and echinomycin each affect the expression of nearly every gene induced by hypoxia. Remarkably, the total number of genes affected by either polyamide or HIF- $1 \alpha$ siRNA over a range of thresholds is comparable. The data show that polyamides can be used to affect a subset of a pathway regulated by a transcription factor. In addition, this study offers a unique comparison of three complementary approaches towards exogenous control of endogenous gene expression.

Exogenous chemical and biological methods to control directly the expression of selected endogenous genes could have broad implications for human medicine. Toward this goal, a number of technological approaches are currently being investigated. Polydactyl zinc finger proteins are a programmable class of DNA binding proteins capable of sequence-specific binding $(1,2)$. These designed proteins have been used to inhibit expression of target genes (3), and transcriptional activator domain-zinc finger conjugates have been used to activate expression of target genes (4). The RNA interference (RNAi) pathway can be used to regulate gene expression at the post-transcriptional level (5). Small interfering RNA and short-hairpin RNA molecules enlist cellular machinery to degrade selected messenger RNA (mRNA) targets $(6,7)$. RNAi technology has been highly effective in achieving potent and specific knockdown of target mRNAs and is now widely used to probe target gene function (8). However, bio-availability and delivery of zinc finger proteins and siRNA to targets in humans could be an obstacle to their therapeutic application and continues to receive considerable attention (8). Cell-permeable small molecules that modulate protein-protein or protein-DNA interactions offer another approach to the control of endogenous gene regulation. Screening small-molecule and natural-product libraries for a desired effect can identify candidate molecules with high likelihoods of possessing drug-like bioavailability; drawbacks include the need to screen anew for each target protein-protein or protein-DNA

*Corresponding author, dervan@ caltech.edu.

Accession Codes: Data have been deposited in NCBIs Gene Expression Omnibus (GEO, www.ncbi.nlm.gov/projects/geo), accessible through GEO Series accession number GSE7535.

Supporting Information Available: This material is available free of charge via the Internet. 
interaction. Polyamides containing $N$-methylimidazole (Im) and $N$-methylpyrrole (Py) are a class of programmable DNA-binding small molecules previously used to disrupt proteinDNA interactions in a sequence-specific manner in cell culture $(9,10)$ (Figure 1).

Controlling the transcriptional activity of hypoxia inducible factor (HIF-1), a heterodimer of HIF- $1 \alpha$ and HIF-1 $\beta$ (ARNT), is a clinically relevant goal (11-14). HIF-1 is the principal mediator of the adaptive cellular response to hypoxia (15). Under normoxic conditions, HIF- $1 \alpha$ is specifically hydroxylated by an iron-dependent proline hydroxylase, ubiquitinated by the von Hippel-Lindau (VHL) tumor suppressor protein-ubiquitin ligase protein complex, and degraded by the proteosome (16). Iron chelators, such as deferoxamine (DFO), can be used to mimic hypoxia in cell culture (16). Through interaction with coactivators p300/CBP, HIF-1 directly activates the expression of at least 100 genes involved in cellular and tissue adaptation to hypoxia (13), including pro-angiogenic factors such as vascular endothelial growth factor (VEGF), glycolytic enzymes, extracellular matrix remodeling enzymes, and genes involved in both pro-survival and death pathways (11). HIF-1 activation by the hypoxic microenvironment of solid tumors or by deactivating mutations in VHL contributes to an aggressive phenotype of increased cell proliferation, invasion, metastasis, and drug resistance (11). Given the complexity of HIF-1 signaling in cellular survival and death pathways and its critical role in physiological processes in normal tissues, it could be advantageous to target a subset of HIF-1 effectors rather than the entire pathway (13).

In important proof of principle experiments, the introduction of siRNA against HIF- $2 \alpha$ to $\mathrm{VHL}^{-1-}$ renal carcinoma cells was sufficient to abrogate tumor formation by these cells in mice (17). Screening for small molecules capable of disrupting the HIF-1-p300 interaction identified chetomin, a natural product that binds $\mathrm{p} 300$, which was shown to inhibit expression of HIF-1 regulated genes and exhibit antitumor activity in a mouse model (18). In an effort to inhibit directly HIF-1-DNA binding, a hairpin polyamide was designed to bind the sequence 5'-ATACGT-3' found in the VEGF hypoxia response element (HRE). This polyamide bound its target site and prevented HIF-1-DNA binding in a sequencespecific manner and inhibited hypoxia-induced expression of VEGF and several other HIF-1 regulated genes in cultured cells without the use of transfection agents $(19,20)$. Melillo and colleagues screened a library of small molecules for inhibition of HIF-1 mediated transcription in a cell-based assay and identified the natural product echinomycin, a DNAbinding bisintercalator (21). Echinomycin binds the four-base-pair sequence 5'-NCGN-3' found in the consensus HRE 5'-NACGTG-3' and inhibited expression of VEGF in cultured cells (22).

To establish a benchmark of comparison for the global effects of polyamides, we compare the genome-wide effects on U251 cells induced with DFO of a polyamide targeted to the HRE sequence 5'-WTWCGW-3', echinomycin, and siRNA targeted against HIF- $1 \alpha$. siRNAmediated destruction of HIF- $1 \alpha$ mRNA establishes a maximum level of inhibition that can be achieved for HIF-1 target genes through disruption of the HIF-1-HRE interaction. Nearly all transcripts induced by DFO are inhibited by both HIF-1 $\alpha$ siRNA and echinomycin. Polyamide 1 inhibits only a subset of these genes and shows a preference for genes containing HREs of the sequence 5'-(T/A)ACGTG-3', consistent with this molecule's predicted binding preferences. Remarkably, the total number of genes affected by either polyamide 1 or HIF- $1 \alpha$ siRNA over a range of thresholds is comparable. We show that HIF-1 occupancy at the HREs of two genes affected by polyamide $\mathbf{1}$ is reduced in the presence of the polyamide, while HIF-1 occupancy at the HREs of one unaffected genes is unchanged. We also show that a polyamide that binds a site immediately $5^{\prime}$ to the VEGF HRE inhibits induced expression of VEGF but not of FMS-like tyrosine kinase 1 (FLT1, 
also known as vascular endothelial growth factor receptor), an HIF-1 target gene lacking this flanking site.

\section{RESULTS AND DISCUSSION}

\section{Binding of Polyamides 1, 2, 3 and Echinomycin at the VEGF and FLT1 HREs}

Polyamide sequence specificity is programmed by side-by-side pairings of heterocyclic amino acids in the minor groove of DNA: Im/Py distinguishes G.C from C.G; Py/Py binds both $\mathrm{A} \cdot \mathrm{T}$ and $\mathrm{T} \cdot \mathrm{A}$; and 3 -chlorothiophene/Py $(\mathrm{Ct} / \mathrm{Py})$ prefers $\mathrm{T} \cdot \mathrm{A}$ at the $\mathrm{N}$-terminus position (23-25). Polyamide 1 and echinomycin are expected to bind at the VEGF HRE sequence 5'TACGTG-3'. Polyamide 2 is expected to bind the sequence $5^{\prime}$-AGTGCA- $3^{\prime}$ immediately $5^{\prime}$ to the VEGF promoter HRE. HRE-mismatch control polyamide 3 targets the sequence 5'WGGWCW-3', which is not found near the VEGF HRE. The DNA-binding affinities of 2 , $\mathbf{3}$, and echinomycin for the VEGF HRE were measured by quantitative DNase I footprint titrations using a $5^{\prime}{ }^{32} \mathrm{P}$-labeled polymerase chain reaction (PCR) amplification product of the plasmid pGL2-VEGF-Luc containing the VEGF HRE (Figure 2, panels a and b). Polyamide 1 was previously found to bind the VEGF HRE $\left(K_{\mathrm{a}}=2.6( \pm 0.4) \times 10^{10} \mathrm{M}^{-1}\right)$ (20). For ease of comparison, a footprinting gel of $\mathbf{1}$ is included. Polyamide $\mathbf{2}$ binds the site $5^{\prime}$-AGTGCA-3' immediately $5^{\prime}$ to the VEGF HRE $\left(K_{\mathrm{a}}=3.2( \pm 0.6) \times 10^{9} \mathrm{M}^{-1}\right)$. Echinomycin binds the VEGF HRE $\left(K_{\mathrm{a}}=8.4( \pm 2.1) \times 10^{6} \mathrm{M}^{-1}\right)$. Polyamide 3 binds the VEGF HRE $\left(K_{\mathrm{a}}=8.0( \pm 1.0) \times 10^{8} \mathrm{M}^{-1}\right)$ and $\sim 35$ base pairs $3^{\prime}$ of the HRE, most likely two $5^{\prime}$-WGWCW-3' sites $\left(K_{\mathrm{a}}=7.6( \pm 1.0) \times 10^{8} \mathrm{M}^{-1}\right)$.

The DNA-binding affinities of $\mathbf{1}, \mathbf{2}, \mathbf{3}$, and echinomycin for the HRE of FLT1 were measured by quantitative DNase I footprint titrations using a $5^{\prime}{ }^{32} \mathrm{P}$-labeled PCR amplification product of the plasmid pCSJ-FLT1 (Figure 2, panels $\mathrm{c}$ and d). Although formally targeted to the sequence $5^{\prime}$-WTWCGW-3', polyamide 1 would be expected to bind 5'-CAACGT-3', albeit with a moderate decrease in affinity (25). The sequence preference of a Ct/Py pair for T.A is $\sim$-fold over A.T but 50-fold over a G.C (25). Polyamide 1 binds the FLT1 HRE $\left(K_{\mathrm{a}}=2.7( \pm 0.2) \times 10^{9} \mathrm{M}^{-1}\right)$. Polyamide 2 binds the FLT1 HRE $\left(K_{\mathrm{a}}=2.2( \pm 0.8)\right.$ $\left.\times 10^{8} \mathrm{M}^{-1}\right)$. Echinomycin binds the FLT1 HRE $\left(K_{\mathrm{a}}=2.9( \pm 0.7) \times 10^{7} \mathrm{M}^{-1}\right)$. Polyamide 3 does not bind the FLT1 HRE with a measurable $K_{\mathrm{a}}$ but was observed to bind a $5^{\prime}-$ AGACA-3' site 16 base pairs $5^{\prime}$ to the FLT1 HRE $\left(K_{\mathrm{a}}=2.7( \pm 0.4) \times 10^{9} \mathrm{M}^{-1}\right)$. These $K_{\mathrm{a}}$ data are summarized in Supplementary Table 1.

\section{Suppression of Induced VEGF and FLT1 Expression}

HIF-1 induces VEGF expression by binding to the 5'-TACGTG-3' HRE located $~ 950$ base pairs upstream of the transcription start site $(26,27)$. The effect on induced VEGF expression by siRNA silencing of HIF-1 $\alpha$ mRNA establishes a theoretical maximum level of inhibition through disruption of HIF-1-DNA binding. HIF- $1 \alpha$ mRNA was reduced by approximately 95\% in the presence of HIF-1 $\alpha$ siRNA but was minimally affected by polyamides $\mathbf{1}$ or 2 or echinomycin under induced conditions (Figure 3). A mismatch control siRNA did not reduce HIF- $1 \alpha \mathrm{mRNA}$. Polyamides 1 and $\mathbf{2}(1 \mu \mathrm{M})$ and HIF- $1 \alpha$ siRNA had similar effects on induced VEGF expression; treatment inhibited most of the increase in VEGF mRNA following DFO treatment but not to levels below that observed for noninduced controls (Figure 3, panel a). As previously reported, $100 \mathrm{nM}$ echinomycin potently inhibits VEGF expression to levels below the noninduced control (21). HRE-mismatch control polyamide $\mathbf{3}$, which binds the HRE with an affinity much reduced relative to that of $\mathbf{1}$, had a more modest effect on VEGF mRNA levels. It is also possible that the modest but measurable effect of polyamide 3 on VEGF expression could be due to interference with other proteinDNA interactions elsewhere in the promoter or enhancer of VEGF or to secondary effects 
from direct effects on other genes. A mismatch control siRNA had a limited effect on VEGF mRNA levels.

Induction of FLT1 (VEFG receptor type 1) is mediated by HIF-1 binding to the 5'AACGTG-3' HRE in the FLT1 promoter (28). Polyamide 1 and HIF-1 $\alpha$ siRNA both inhibited FLT1 expression following DFO induction (Figure 3, panel b). Echinomycin reduced FLT1 expression to below that of the noninduced control. Polyamides $\mathbf{2}$ and $\mathbf{3}$ had minimal effect. A mismatch control siRNA also had a limited effect on FLT1 mRNA levels. Given the relative binding affinities of polyamide $\mathbf{1}$ and echinomycin, it may be surprising that $1 \mu \mathrm{M}$ of polyamide 1 is necessary to inhibit VEGF and FLT1 expression comparably to HIF-1 $\alpha$ siRNA, whereas $100 \mathrm{nM}$ echinomycin reduces their expression to sub-basal levels. The structure of double-helical DNA is not greatly perturbed by minor groove-binding hairpin polyamides (23); echinomycin-DNA binding causes local unwinding and lengthening of the DNA helix, which might account for its greater potency in these experiments $(29,30)$. Polyamide-intercalator conjugates have been shown to unwind DNA in a sequence-specific fashion and to improve the ability of a polyamide to inhibit binding of several DNA-binding proteins in vitro $(31,32)$. Attempts to use polyamide-intercalator conjugates to target the VEGF HRE have not been successful because of poor nuclear uptake.

The ability to target DNA sequences flanking critical protein-DNA binding sites while maintaining productive inhibition of protein-DNA binding expands the repertoire of such interactions amenable to inhibition by polyamides. In a similar approach, Kageyama et al. showed that polyamides targeted to sequences flanking the VEGF HRE could inhibit VEGF expression (33). Polyamides targeted to flanking sites have previously successfully inhibited protein-DNA binding in the cases of TATA-binding protein and LEF-1 (34). It should be noted that minor groove-binding polyamides and some major groove-binding proteins cooccupy DNA sequences in some cases (35).

\section{Microarray Analysis of Gene Expression}

One potential limitation to the use of hairpin polyamides for gene regulation is binding site size and specificity for match versus mismatch sites, which may result in prohibitively large numbers of affected genes. To examine this, the global effects of polyamide treatment on hypoxia-induced gene expression were measured using Affymetrix Human Genome U133 Plus 2.0 Arrays containing oligonucleotide sequences representing $>50,000$ transcripts. To establish a benchmark for comparison, the effects of HIF- $1 \alpha$ siRNA and echinomycin were also measured. Experiments were conducted in triplicate, and gene expression levels normalized to DFO-treated controls. Cells not treated with DFO were normalized to DFOtreated controls.

Polyamide $1(1 \mu \mathrm{M})$ affected expression of 2,284 transcripts by $>2$-fold $(p \leq 0.01)$ (Table 1$)$. At the same threshold, HIF-1 $\alpha$ siRNA affected 3190 transcripts and echinomycin (100 nM) affected 10,906. In all cases, a majority of affected genes were down-regulated. For comparison, DFO treatment alone affected expression of 2142 transcripts (4.6\% of interrogated transcripts), with a majority up-regulated. Clustering analysis was performed to identify similarities in the expression profiles between the different treatments (Figure 4). The expression profile of cells treated with HIF-1 $\alpha$ siRNA is similar to that of cells not treated with DFO under the conditions of the analysis; the expression profiles of echinomycin-treated and polyamide-treated cells are less similar to each other and to the other treatments. Analysis of transcripts affected by both $\mathbf{1}$ and HIF- $1 \alpha$ siRNA shows that 395 and 150 transcripts are commonly down- and up-regulated, respectively, at least 2-fold $(p \leq 0.01)$. A similar analysis of transcripts affected by both $\mathbf{1}$ and echinomycin shows that 731 and 112 transcripts are commonly down- and up-regulated, respectively. Analysis of 
transcripts affected by both siRNA and echinomycin shows that 1140 and 443 transcripts are commonly down- and up-regulated, respectively. A side-by-side, genome-wide expression analysis of fluorescein-tagged analogues of polyamides $\mathbf{1}$ and $\mathbf{3}$ in DFO-induced cells was previously reported (19), and it was found that a majority of genes were uniquely affected by each polyamide, with a number of genes commonly affected, under the conditions of the experiments. It is not entirely unsurprising that there is some overlap in genes affected by polyamides targeted to different DNA sequences, given that we do not have a full understanding of all DNA sequences involved in the direct or indirect regulation of a given gene.

We find that DFO induced the expression of a set of 297 transcripts by at least 4-fold ( $p \leq$ 0.01 ) (Figure 4, panel b). Of this set, 69 were inhibited by polyamide 1 by at least 2 -fold ( $p$ $\leq 0.01$ ). For comparison, HIF-1 $\alpha$ siRNA inhibited 244, and echinomycin 263 of the 297 DFO-induced transcripts. It is not known what proportion of these affected transcripts are direct HIF-1 targets. To examine more closely the effects of polyamide 1, HIF-1 $\alpha$ siRNA, and echinomycin on transcripts induced directly by HIF-1, we examined a limited set of 31 transcripts consisting of previously identified direct HIF-1 targets that were induced at least 1.5 -fold $(p \leq 0.01)$ by DFO in this experiment (Figure 4, panel c) $(28,36-45)$. Nearly all 31 transcripts in this set were down-regulated by HIF-1 $\alpha$ siRNA. In most cases, the expression was reduced to levels observed in cells untreated with DFO. Echinomycin treatment resulted in down-regulation of all 31 transcripts. For some genes, including VEGF, expression was reduced to levels far below those of the siRNA-treated cells and noninduced controls. Polyamide 1 inhibited the expression of 14 of these but displayed minimal effect on the others.

The HRE sequences for these genes, where known, are displayed in Table 2. Quantitative real-time reverse transcriptase PCR (RT-PCR) was used to confirm the effects of polyamides $\mathbf{1}, \mathbf{3}$, echinomycin, and siRNA treatments on these 11 genes. RT-PCR confirms that siRNA and echinomycin reduced expression of all genes in this set. Polyamide 1 significantly affected four genes in this set. Polyamide $\mathbf{3}$ had a modest but measurable effect on VEGF expression but little effect on the expression of all the others. Chromatin immunoprecipitation was used to measure HIF-1 occupancy at the HREs of VEGF and carbonic anhydrase IX (CA9), which were both affected by polyamide 1, and PGK1, which was unaffected (Figure 5). HIF-1 $\alpha$ occupancy at the VEGF HRE was decreased by HIF-1 $\alpha$ siRNA, echinomycin, and polyamide 1 but less so by treatment with HRE-mismatch polyamide 3. HIF-1 occupancy at the CA9 locus was also decreased by HIF-1 $\alpha$ siRNA, echinomycin, and polyamide $\mathbf{1}$ but was unaffected by $\mathbf{3}$. HIF-1 occupancy at PGK1 was markedly decreased by siRNA but minimally affected by polyamide $\mathbf{1}$ or $\mathbf{3}$. Surprisingly, echinomycin did not appear to affect HIF-1 occupancy at this locus. It is interesting to note that all of the genes affected by polyamide 1 displayed in Table 1 have HREs that fall within the sequence 5'-(T/A)ACGTG-3', consistent with the expected DNA binding preferences for this molecule.

\section{Conclusions and Significance}

In this experiment, polyamide $\mathbf{1}(1 \mu \mathrm{M})$ affected expression of 2,284 transcripts by $>2$-fold $(p \leq 0.01)$, which represents $<5 \%$ of transcripts assayed. A search of the publicly available human genome for the sequence $5^{\prime}$-WTWCGW-3' finds 1,876,480 potential match sites for polyamide 1 . This corresponds to an average of 1 binding site every 1600 base pairs. The proportion of these sites accessible to polyamide binding in the context of heterochromatin in vivo is currently unknown. Additionally, data from in vitro transcription experiments suggest that polyamides noncovalently bound within the coding region of a gene would not interfere with RNA polymerase activity at that locus (34). It would thus not be surprising if a significant fraction of polyamide-DNA binding events in a cell do not directly affect gene 
expression. In parallel to this, global analysis of transcription factor binding to chromatin in vivo has shown occupancy at promoters and enhancers without associated changes in gene expression at that locus (46).

Interestingly, polyamide $1(1 \mu \mathrm{M})$ affected the expression of fewer genes than HIF-1 $\alpha$ siRNA under the conditions of the experiment. A direct comparison in genomic specificity between polyamide and siRNA cannot be drawn from these limited data, because a large proportion of the genes affected by siRNA are likely a result of silencing the target gene, HIF-1 $\alpha$, rather than off-target effects involving post-transcriptional silencing of mRNA using the RNAi pathway (47). If we eliminate from the total number of transcripts affected by the HIF- $1 \alpha$ siRNA ( 2 -fold, $p \leq 0.01$ ) all transcripts affected by treatment with DFO alone (1.5-fold, $p \leq 0.01$ ), we are left with 1523 affected transcripts. A similar treatment of the data for polyamide 1 results in 1626 affected transcripts. It should also be noted that, for most HIF-1 regulated genes affected by both polyamide and siRNA, inhibition by the polyamide was more modest than by siRNA, suggesting incomplete abrogation of HIF-1 DNA binding by the polyamide. Polyamide 1 inhibited $23 \%$ of the 297 transcripts induced by DFO. For genes where the functional HRE has been identified, the effects of treatment with polyamide 1 or echinomycin are, thus far, consistent with the expected binding preferences of these molecules.

HIF-1 is frequently overactive in tumors, and a number of direct targets in the HIF-1 pathway have become points of clinical intervention (48). Bevacizumab, an anti-VEGF antibody, and sorafenib and sunitinib, tyrosine kinase inhibitors with activity against the VEGF receptors, have shown some promise in clinical trials as cancer therapeutics (49-51). Echinomycin had been previously brought to the clinic as a cancer therapeutic in phase I and II trials (52), based on observations that echinomycin exhibits potent antiproliferative effects on several tumor-derived cell lines $(52,53)$. However, survival benefit was not established (52). In light of recent work by Melillo and colleagues, re-examination of the clinical use of echinomycin in tumor types expected to be highly sensitive to HIF-1 activity may be justified (21).

The induction of pro-angiogenic, proliferative, metastatic, and glycolytic genes by HIF-1 are established as contributing to the cancer phenotype (11). Genes that promote cell death, such as BNIP3 and NIX (BNIP3L), are also induced by hypoxia through HIF-1 (54). In this sense, HIF-1 plays dual roles in the survival and death pathways of tumor cells (12). A functional separation of these targets of HIF-1 at the level of HIF-1-DNA binding might have clinical relevance (12). Given sufficient knowledge of the particular regulatory sequences involved, one could, in principle, design a polyamide or cocktail of polyamides to affect a selected subset of target genes in the HIF-1 pathway, making use of the programmability of polyamide recognition for targeting particular HREs and flanking sequences. The utility of polyamides as regulators of hypoxia-induced gene expression awaits continued study in small-animal models of HIF-1 activity.

\section{METHODS}

\section{Synthesis of Polyamides}

Polyamides were synthesized by solid-phase methods on Kaiser oxime resin (Nova Biochem), cleaved from the resin with 3,3'-diamino- $N$-methyl-dipro-pylamine, and purified by reverse-phase HPLC (55). Isophthalic acid was activated with PyBOP (Nova Biochem) and conjugated to the polyamides as previously described (20). Purity and identity of polyamides assessed by HPLC, UV-visible spectroscopy, and MALDI TOFMS (Supplementary Figure 1). 


\section{Determination of DNA-Binding Affinities and Sequence Specificities}

Quantitative DNase I footprint titration experiments were used to measure the binding affinities of polyamides $\mathbf{1}, \mathbf{2}, \mathbf{3}$, and echinomycin on $5^{\prime 32} \mathrm{P}$-labeled fragments of pGL2VEGF-Luc and pCSJ-FLT1 containing promoter sequences containing the HREs of VEGF and FLT1, respectively. Quantitative DNase I footprint titration experiments were conducted as reported previously (56).

\section{Measurement of Hypoxia-Induced Gene Expression}

U251 cells were plated in 24-well plates at a density of $20-30 \times 10^{3}$ cells per well (40-60 $\times$ $10^{3}$ cells $\mathrm{mL}^{-1}$ ) in Roswell Park Memorial Institute medium (ATCC) supplemented with $5 \%$ fetal bovine serum (Irvine Scientific). After $24 \mathrm{~h}$, polyamides were added to the adhered cells in cell media solutions at the appropriate concentration and incubated with the cells for $48 \mathrm{~h}$. Hypoxic induction of gene expression was chemically induced by adding DFO to 300 $\mu \mathrm{M}$ for an additional $16 \mathrm{~h}$. When appropriate, echinomycin was added $2 \mathrm{~h}$ prior to DFO stimulation. Isolation of RNA and subsequent complementary DNA synthesis were as previously described (19). When appropriate, HIF-1 $\alpha$ siRNA (HIF-1 $\alpha$ validated stealth duplex, Invitrogen) or mismatch control siRNA with similar GC content (Invitrogen) was transfected $48 \mathrm{~h}$ prior to RNA isolation. Transfection of siRNA was achieved using Lipofectamine 2000 (Invitrogen) according to the manufacturer's protocols. Quantitative realtime RT-PCR was performed using SYBR Green PCR Master Mix (Applied Biosystems) on an ABI 7300 instrument. Target gene mRNA was measured relative to $\beta$-glucuronidase as an endogenous control. Primers employed were VEGF, L 5'-

AGGGCAGAATCATCACGAAG-3', R 5'-GGGTACTCC-TGGAAGATGTCC-3'; $\beta$ glucuronidase, L 5'-CTCATTTGGAATTTTGCC-GATT-3', R 5'CCGAGTGAAGATCCCCTTTTTA-3'; FLT1, L 5'-CAGCAACATGGGAAACAGAAT-3', R 5'-TAGAGTCAGCCACAACCAAGG-3'.

\section{Chromatin Immunoprecipitation}

U251 cells were plated in 15-cm-diam plates and left to attach overnight. Media, time course, DFO, polyamide, echinomycin, and siRNA treatments were as described above. After the 16-h DFO treatment, cells were treated with $1 \%$ formaldehyde for $10 \mathrm{~min}$. Chromatin was isolated and sheared. HIF-1 $\alpha$ antibodies (Novus Biologicals) were used to immunoprecipitate HIF-1 bound DNA fragments. After cross-link reversal, PCRs using primers targeted to the regions of interest were used to assess enrichment of bound fragments as compared to mock-precipitated (no antibody) controls. PCRs were monitored either using SYBR Green PCR Master Mix (Applied Biosystems) on an ABI 7300 instrument or directly visualized using gel electrophoresis. The following primers were used: VEGF, L 5'-CCTTTGGGTTTTGCCAGA-3', R 5'-CCAAGTTTGTGGAGCTGA-3'; CA9, L 5'-AAAAGGGCGCTCTGTGAGT-3', R 5'-GCTGACTGTGGGGT-GTCC-3'; PGK1, L 5'-CCCCTAAGTCGGGAAGGTT-3', R 5'-GTCCGTCTGCGAGGGTACTA-3'.

\section{Analysis of Gene Expression with Oligonucleotide Microarrays}

U251 cells were plated in 12-well plates at a density of 40-60 $\times 10^{3}$ cells per well. Media, time course, DFO, polyamide, echinomycin, and siRNA treatments were as described above. RNA was isolated as previously described. Further sample preparation for microarray experiments was carried out at the Millard and Muriel Jacobs Gene Expression Facility at Caltech. Labeled mRNA was hybridized to Affymetrix Human 133 arrays according to established protocols. Gene expression was analyzed using Resolver (Rosetta Biosoftware, Seattle). 


\section{Supplementary Material}

Refer to Web version on PubMed Central for supplementary material.

\section{References}

1. Blancafort P, Segal DJ, Barbas CF. Designing transcription factor architectures for drug discovery. Mol Pharmacol. 2004; 66:1361-1371. [PubMed: 15340042]

2. Beerli RR, Barbas CF. Engineering polydactyl zinc-finger transcription factors. Nat Biotechnol. 2002; 20:135-141. [PubMed: 11821858]

3. Beerli RR, Segal DJ, Dreier B, Barbas CF. Toward controlling gene expression at will: specific regulation of the erbB-2/HER-2 promoter by using polydactyl zinc finger proteins constructed from modular building blocks. Proc Natl Acad Sci USA. 1998; 95:14628-14633. [PubMed: 9843940]

4. Liu PQ, Rebar EJ, Zhang L, Liu Q, Jamieson AC, Liang Y, Qi H, Li PX, Chen B, Mendel MC, Zhong X, Lee YL, Eisenberg SP, Spratt SK, Case CC, Wolffe AP. Regulation of an endogenous locus using a panel of designed zinc finger proteins targeted to accessible chromatin regionsactivation of vascular endothelial growth factor A. J Biol Chem. 2001; 276:11323-11334. [PubMed: 11145970]

5. Fire A, Xu SQ, Montgomery MK, Kostas SA, Driver SE, Mello CC. Potent and specific genetic interference by double-stranded RNA in Caenorhabditis elegans. Nature. 1998; 391:806-811. [PubMed: 9486653]

6. Meister G, Tuschl T. Mechanisms of gene silencing by double-stranded RNA. Nature. 2004; 431:343-349. [PubMed: 15372041]

7. Mello CC, Conte D. Revealing the world of RNA interference. Nature. 2004; 431:338-342. [PubMed: 15372040]

8. Hannon GJ, Rossi JJ. Unlocking the potential of the human genome with RNA interference. Nature. 2004; 431:371-378. [PubMed: 15372045]

9. Dervan PB, Edelson BS. Recognition of the DNA minor groove by pyrrole-imidazole polyamides. Curr Opin Struct Biol. 2003; 13:284-299. [PubMed: 12831879]

10. Nickols NG, Dervan PB. Suppression of androgen receptor-mediated gene expression by a sequence-specific DNA-binding polyamide. Proc Natl Acad Sci USA. 2007; 104:10418-10423. [PubMed: 17566103]

11. Semenza GL. Targeting HIF-1 for cancer therapy. Nat Rev Cancer. 2003; 3:721-732. [PubMed: 13130303]

12. Zhou J, Schmid T, Schnitzer S, Brune B. Tumor hypoxia and cancer progression. Cancer Lett. 2006; 237:10-21. [PubMed: 16002209]

13. Pouyssegur J, Dayan F, Mazure NM. Hypoxia signalling in cancer and approaches to enforce tumour regression. Nature. 2006; 441:437-443. [PubMed: 16724055]

14. Melillo G. Inhibiting hypoxia-inducible factor 1 for cancer therapy. Mol Cancer Res. 2006; 4:601605. [PubMed: 16940159]

15. Semenza GL. HIF-1 and human disease: one highly involved factor. Genes Dev. 2000; 14:19831991. [PubMed: 10950862]

16. Ivan M, Kondo K, Yang HF, Kim W, Valiando J, Ohh M, Salic A, Asara JM, Lane WS, Kaelin WG. HIF alpha targeted for VHL-mediated destruction by proline hydroxylation: implications for O-2 sensing. Science. 2001; 292:464-468. [PubMed: 11292862]

17. Zimmer M, Doucette D, Siddiqui N, Iliopoulos O. Inhibition of hypoxia-inducible factor is sufficient for growth suppression of VHL-/- tumors. Mol Cancer Res. 2004; 2:89-95. [PubMed: 14985465]

18. Kung AL, Zabludoff SD, France DS, Freedman SJ, Tanner EA, Vieira A, Cornell-Kennon S, Lee J, Wang BQ, Wang J, Memmert K, Naegeli HU, Petersen F, Eck MJ, Bair KW, Wood AW, Livingston DM. Small molecule blockade of transcriptional coactivation of the hypoxia-inducible factor pathway. Cancer Cell. 2004; 6:33-43. [PubMed: 15261140] 
19. Olenyuk BZ, Zhang GJ, Klco JM, Nickols NG, Kaelin WG, Dervan PB. Inhibition of vascular endothelial growth factor with a sequence-specific hypoxia response element antagonist. Proc Natl Acad Sci USA. 2004; 101:16768-16773. [PubMed: 15556999]

20. Nickols NG, Jacobs CS, Farkas ME, Dervan PB. Improved nuclear localization of DNA-binding polyamides. Nucleic Acids Res. 2007; 35:363-370. [PubMed: 17175539]

21. Kong DH, Park EJ, Stephen AG, Calvani M, Cardellina JH, Monks A, Fisher RJ, Shoemaker RH, Melillo G. Echinomycin, a small-molecule inhibitor of hypoxia-inducible factor-1 DNA-binding activity. Cancer Res. 2005; 65:9047-9055. [PubMed: 16204079]

22. Van Dyke MM, Dervan PB. Echinomycin binding-sites on DNA. Science. 1984; 225:1122-1127. [PubMed: 6089341]

23. Kielkopf CL, Baird EE, Dervan PD, Rees DC. Structural basis for G.C recognition in the DNA minor groove. Nat Struct Biol. 1998; 5:104-109. [PubMed: 9461074]

24. White S, Szewczyk JW, Turner JM, Baird EE, Dervan PB. Recognition of the four Watson-Crick base pairs in the DNA minor groove by synthetic ligands. Nature. 1998; 391:468-471. [PubMed: 9461213]

25. Foister S, Marques MA, Doss RM, Dervan PB. Shape selective recognition of T A base pairs by hairpin polyamides containing N-terminal 3-methoxy (and 3-chloro) thiophene residues. Bioorg Med Chem. 2003; 11:4333-4340. [PubMed: 13129569]

26. Liu YX, Cox SR, Morita T, Kourembanas S. Hypoxia regulates vascular endothelial growth-factor gene-expression in endothelial-cells-Identification of a 5'-enhancer. Circ Res. 1995; 77:638-643. [PubMed: 7641334]

27. Forsythe JA, Jiang BH, Iyer NV, Agani F, Leung SW, Koos RD, Semenza GL. Activation of vascular endothelial growth factor gene transcription by hypoxia-inducible factor 1 . Mol Cell Biol. 1996; 16:4604-4613. [PubMed: 8756616]

28. Gerber HP, Condorelli F, Park J, Ferrara N. Differential transcriptional regulation of the two vascular endothelial growth factor receptor genes-Flt-1, but not Flk-1/KDR, is up-regulated by hypoxia. J Biol Chem. 1997; 272:23659-23667. [PubMed: 9295307]

29. Waring MJ, Wakelin LPG. Echinomycin-bifunctional intercalating antibiotic. Nature. 1974; 252:653-657. [PubMed: 4437614]

30. Low CML, Drew HR, Waring MJ. Sequence-specific binding of echinomycin to DNA-evidence for conformational-changes affecting flanking sequences. Nucleic Acids Res. 1984; 12:48654879. [PubMed: 6204275]

31. Fechter EJ, Dervan PB. Allosteric inhibition of protein-DNA complexes by polyamide-intercalator conjugates. J Am Chem Soc. 2003; 125:8476-8485. [PubMed: 12848553]

32. Fechter EJ, Olenyuk B, Dervan PB. Design of a sequence-specific DNA bisintercalator. Angew Chem, Int Ed. 2004; 43:3591-3594.

33. Kageyama Y, Sugiyama H, Ayame H, Iwai A, Fujii Y, Huang LE, Kizaka-Kondoh S, Hiraoka M, Kihara K. Suppression of VEGF transcription in renal cell carcinoma cells by pyrrole-imidazole hairpin polyamides targeting the hypoxia responsive element. Acta Oncol. 2006; 45:317-324. [PubMed: 16644575]

34. Dickinson LA, Gulizia RJ, Trauger JW, Baird EE, Mosier DE, Gottesfeld JM, Dervan PB. Inhibition of RNA polymerase II transcription in human cells by synthetic DNA-binding ligands. Proc Natl Acad Sci USA. 1998; 95:12890-12895. [PubMed: 9789010]

35. Oakley MG, Mrksich M, Dervan PB. Evidence that a minor groove-binding peptide and a major groove-binding protein can simultaneously occupy a common site on DNA. Biochemistry. 1992; 31:10969-10975. [PubMed: 1445835]

36. Tacchini L, Bianchi L, Bernelli-Zazzera A, Cairo G. Transferrin receptor induction by hypoxiaHIF-1-mediated transcriptional activation and cell-specific post-transcriptional regulation. J Biol Chem. 1999; 274:24142-24146. [PubMed: 10446187]

37. Lok CN, Ponka P. Identification of a functional hypoxia-response element in the transferrinreceptor gene. Exp Hematol. 1999; 27:91-91.

38. Fukasawa M, Tsuchiya T, Takayama E, Shinomiya N, Uyeda K, Sakakibara R, Seki S. Identification and characterization of the hypoxia-responsive element of the human placental 6- 
phosphofructo-2-kinase/fructose-2,6-bisphosphatase gene. J Biochem. 2004; 136:273-277. [PubMed: 15598882]

39. Obach M, Navarro-Sabate A, Caro J, Kong XG, Duran J, Gomez M, Perales JC, Ventura F, Rosa JL, Bartrons R. 6-Phosphofructo-2-kinase (pfkfb3) gene promoter contains hypoxia-inducible factor-1 binding sites necessary for transactivation in response to hypoxia. J Biol Chem. 2004; 279:53562-53570. [PubMed: 15466858]

40. Semenza GL, Jiang BH, Leung SW, Passantino R, Concordet JP, Maire P, Giallongo A. Hypoxia response elements in the aldolase A, enolase 1, and lactate dehydrogenase A gene promoters contain essential binding sites for hypoxia-inducible factor 1. J Biol Chem. 1996; 271:32529_ 32537. [PubMed: 8955077]

41. Semenza GL, Roth PH, Fang HM, Wang GL. Transcriptional regulation of genes encoding glycolytic-enzymes by hypoxia-inducible factor-1. J Biol Chem. 1994; 269:23757-23763. [PubMed: 8089148]

42. Pescador N, Cuevas Y, Naranjo S, Alcaide M, Villar D, Landazuri M, Del Peso L. Identification of a functional hypoxia-responsive element that regulates the expression of the egl nine homologue 3 (egln3/phd3) gene. Biochem J. 2005; 390:189-197. [PubMed: 15823097]

43. Willam C, Nicholls LG, Ratcliffe PJ, Pugh CW, Maxwell PH. The prolyl hydroxylase enzymes that act as oxygen sensors regulating destruction of hypoxia-inducible factor alpha. Adv Enzyme Regul. 2004; 44:75-92. [PubMed: 15581484]

44. Grabmaier K, de Weijert MCA, Verhaegh GW, Schalken JA, Oosterwijk E. Strict regulation of CAIX(G250/MN) by HIF-1 alpha in clear cell renal cell carcinoma. Oncogene. 2004; 23:56245631. [PubMed: 15184875]

45. Hu J, Discher DJ, Bishopric NH, Webster KA. Hypoxia regulates expression of the endothelin-1 gene through a proximal hypoxia-inducible factor-1 binding site on the antisense strand. Biochem Biophys Res Commun. 1998; 245:894-899. [PubMed: 9588211]

46. Zhang XM, Odom DT, Koo SH, Conkright MD, Canettieri G, Best J, Chen HM, Jenner R, Herbolsheimer E, Jacobsen E, Kadam S, Ecker JR, Emerson B, Hogenesch JB, Unterman T, Young RA, Montminy M. Genome-wide analysis of cAMP-response element binding protein occupancy, phosphorylation, and target gene activation in human tissues. Proc Natl Acad Sci USA. 2005; 102:4459-4464. [PubMed: 15753290]

47. Jackson AL, Bartz SR, Schelter J, Kobayashi SV, Burchard J, Mao M, Li B, Cavet G, Linsley PS. Expression profiling reveals off-target gene regulation by RNAi. Nat Biotechnol. 2003; 21:635637. [PubMed: 12754523]

48. Cohen HT, McGovern FJ. Renal-cell carcinoma. N Engl J Med. 2005; 353:2477-2490. [PubMed: 16339096]

49. Escudier B, Eisen T, Stadler WM, Szczylik C, Oudard S, Siebels M, Negrier S, Chevreau C, Solska E, Desai AA, Rolland F, Demkow T, Hutson TE, Gore M, Freeman S, Schwartz B, Shan M, Simantov R, Bukowski RM. the TARGET Study Group. Sorafenib in advanced clear-cell renal-cell carcinoma. N Engl J Med. 2007; 356:125-134. [PubMed: 17215530]

50. Motzer RJ, Hutson TE, Tomczak P, Michaelson MD, Bukowski RM, Rixe O, Oudard S, Negrier S, Szczylik C, Kim ST, Chen I, Bycott PW, Baum CM, Figlin RA. Sunitinib versus interferon alfa in metastatic renal-cell carcinoma. N Engl J Med. 2007; 356:115-124. [PubMed: 17215529]

51. Yang JC, Haworth L, Sherry RM, Hwu P, Schwartzentruber DJ, Topalian SL, Steinberg SM, Chen HX, Rosenberg SA. A randomized trial of bevacizumab, an anti-vascular endothelial growth factor antibody, for metastatic renal cancer. N Engl J Med. 2003; 349:427-434. [PubMed: 12890841]

52. Foster BJ, Clagettcarr K, Shoemaker DD, Suffness M, Plowman J, Trissel LA, Grieshaber CK, Leylandjones B. Echinomycin-the 1st bifunctional intercalating agent in clinical-trials. Invest New Drugs. 1985; 3:403-410. [PubMed: 3910610]

53. May LG, Madine MA, Waring MJ. Echinomycin inhibits chromosomal DNA replication and embryonic development in vertebrates. Nucleic Acids Res. 2004; 32:65-72. [PubMed: 14704344]

54. Kothari S, Cizeau J, McMillan-Ward E, Israels SJ, Bailes M, Ens K, Kirshenbaum LA, Gibson SB. BNIP3 plays a role in hypoxic cell death in human epithelial cells that is inhibited by growth factors EGF and IGF. Oncogene. 2003; 22:4734-4744. [PubMed: 12879018] 
55. Belitsky JM, Nguyen DH, Wurtz NR, Dervan PB. Solid-phase synthesis of DNA binding polyamides on oxime resin. Bioorg Med Chem. 2002; 10:2767-2774. [PubMed: 12057666]

56. Trauger JW, Dervan PB. Footprinting methods for analysis of pyrrole-imidazole polyamide/DNA complexes. Methods Enzymol. 2001; 340:450-466. [PubMed: 11494863] 


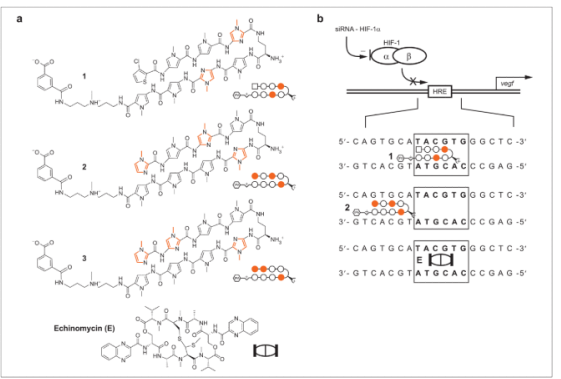

Figure 1.

Structures of molecules used in this study. a) Structures of polyamides 1-3 and echinomycin. Imidazole, pyrrole, and chlorothiophene monomer units are represented by, respectively, closed circles, open circles, and squares. b) Three approaches to inhibiting gene expression induced by HIF-1: sequence-specific small-molecule binding to the HRE by a polyamide or echinomycin and reduction in HIF-1 $\alpha$ mRNA using siRNA. 


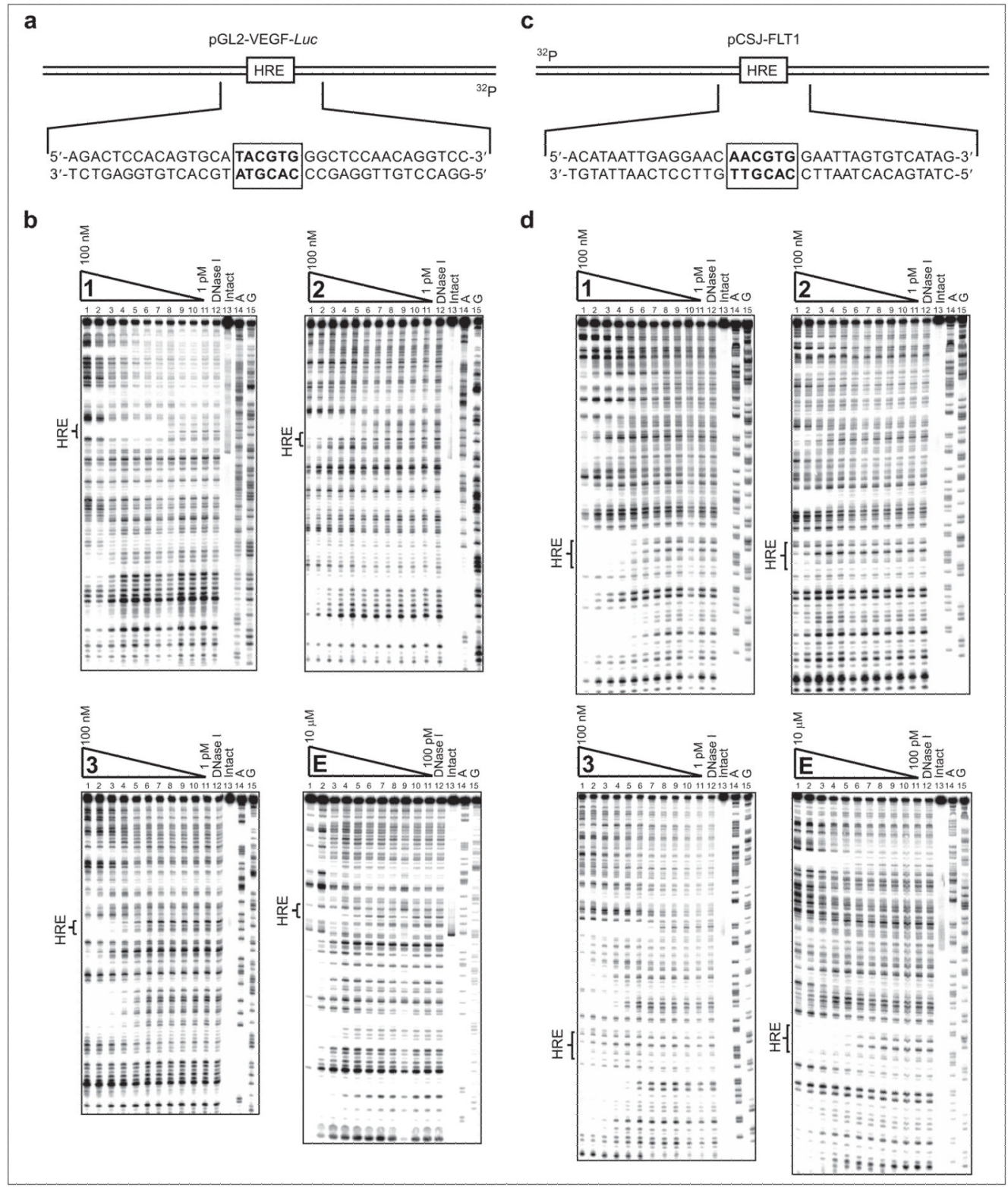

Figure 2.

Quantitative DNase I footprint titration experiments for polyamides 1-3 and echinomycin. a) Illustration of pGL2-VEGF-Luc and partial sequence containing the VEGF HRE and putative binding sites for polyamides 1, 2, and echinomycin. b) Quantitative DNase I footprint titration experiments for polyamides 1, 2, 3, and echinomycin, E, on the 5'-endlabeled PCR product of plasmid pGL2-VEGF-Luc. For polyamides 1, 2, and 3: lanes 1-11, $100 \mathrm{nM}, 30 \mathrm{nM}, 10 \mathrm{nM}, 3 \mathrm{nM}, 1 \mathrm{nM}, 300$ pM, 100 pM, 30 pM, 10 pM, 3 pM, and 1 pM polyamide, respectively; lane 12, DNase I standard; lane 13, intact DNA; lane 14, A reaction; lane $15, \mathrm{G}$ reaction. For echinomycin, E: lanes $1-11,10 \mu \mathrm{M}, 3 \mu \mathrm{M}, 1 \mu \mathrm{M}, 300 \mathrm{nM}$, $100 \mathrm{nM}, 30 \mathrm{nM}, 10 \mathrm{nM}, 3 \mathrm{nM}, 1 \mathrm{nM}, 300$ pM, and 100 pM echinomycin, respectively; lanes $12-15$ as above. Polyamide 1 and echinomycin have $K_{\mathrm{a}}=2.6( \pm 0.4) \times 10^{10} \mathrm{M}^{-1}$ and $K_{\mathrm{a}}=$ $8.4( \pm 2.1) \times 10^{6} \mathrm{M}^{-1}$, respectively, at the VEGF HRE. Polyamide 2 has $K_{\mathrm{a}}=3.2( \pm 0.6) \times$ $10^{9} \mathrm{M}^{-1}$ for the site $5^{\prime}$-AGTGCA-3' immediately $5^{\prime}$ to the VEGF HRE. Polyamide 3 has $K_{\mathrm{a}}$ $=8.0( \pm 1.0) \times 10^{8} \mathrm{M}^{-1}$ for the VEGF HRE. c) Illustration of pCSJ-FLT1 and partial 
sequence containing the FLT1 HRE and putative binding sites for polyamides 1 and echinomycin. d) Quantitative DNase I footprint titration experiments for polyamides 1, 2, 3, and echinomycin (E) on the 5' end-labeled PCR product of plasmid pCSJ-FLT1. Lane assignments for gels shown are as described for panel $\mathrm{b}$. Polyamide 1 and echinomycin have $K_{\mathrm{a}}=2.7( \pm 0.2) \times 10^{9} \mathrm{M}^{-1}$ and $K_{\mathrm{a}}=2.9( \pm 0.7) \times 10^{7} \mathrm{M}^{-1}$, respectively, at the FLT1 HRE. Polyamide 2 has $K_{\mathrm{a}}=2.2( \pm 0.8) \times 10^{8}$ at this site. Polyamide 3 does not bind the FLT1 HRE with a measurable $K_{\mathrm{a}}$. 


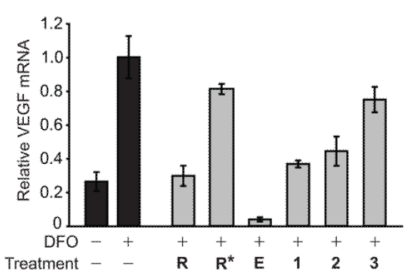

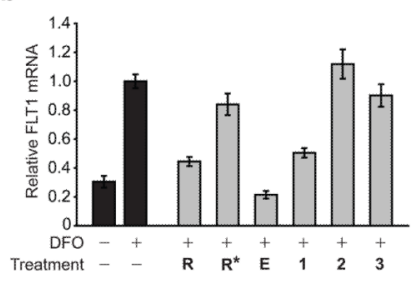

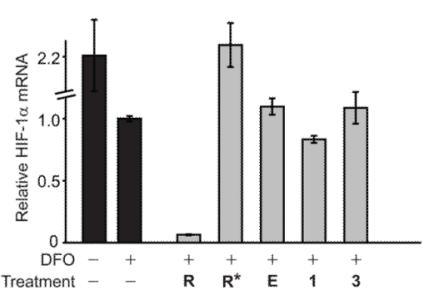

Figure 3.

Quantitative real-time PCR measurements. a) Induction of VEGF mRNA by the hypoxia mimetic (DFO) measured by quantitative real-time PCR: HIF-1 $\alpha$ siRNA, R; mismatch control siRNA, R*; echinomycin (100 nM), E; and polyamides 1 , 2, and $3(1 \mu \mathrm{M})$.

Treatment with siRNA, 1, or 2 decreases VEGF mRNA levels to near-noninduced levels. Echinomycin potently inhibits VEGF mRNA to below noninduced levels. Polyamide 3 has a more modest effect. b) Induction of FLT1 mRNA by DFO measured by quantitative realtime PCR: HIF-1 $\alpha$ siRNA, R; mismatch control siRNA, R*; echinomycin (100 nM), E; and polyamides 1,2 , and $3(1 \mu \mathrm{M})$. The siRNA, echinomycin, and 1 decrease FLT1 mRNA levels. Polyamides 2 and 3 have minimal or no effect. c) Measurement of HIF-1 $\alpha$ mRNA by quantitative real-time PCR: HIF-1 $\alpha$ siRNA, R; mismatch control siRNA, R*; echinomycin $(100 \mathrm{nM}), \mathrm{E}$; and polyamides 1 and $3(1 \mu \mathrm{M})$. Treatment with siRNA decreases HIF-1 $\alpha$ mRNA by $>95 \%$. 


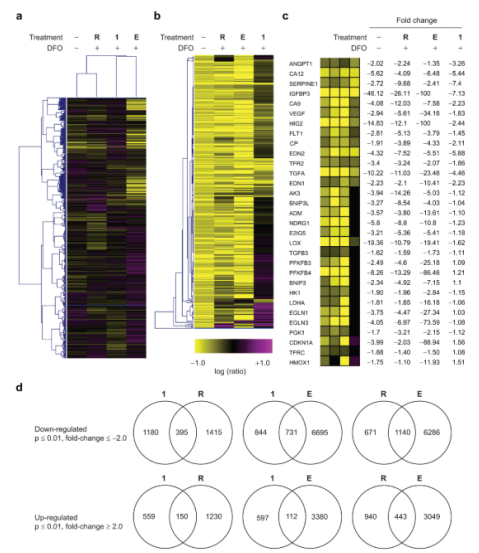

\section{Figure 4.}

Microarray analysis of gene expression. a) Divisive clustering analysis over all interrogated transcripts for DFO-induced cells: HIF-1 $\alpha$ siRNA, R; echinomycin (100 nM), E; and

polyamides $1(1 \mu \mathrm{M})$. b) Agglomerative clustering analysis over all 297 transcripts induced by DFO $\geq 4$-fold ( $p \leq 0.01$ ). Of this transcript set, HIF- $1 \alpha$ siRNA inhibited 244 , echinomycin inhibited 263, and polyamide 1 inhibited 69 by $\geq 2$-fold ( $p \leq 0.01)$. c) Effects of the indicated treatments on a panel of genes previously characterized as direct targets of HIF-1 and also induced by DFO at least 1.5-fold $(p \leq 0.01)$ in this experiment. Treatments reported are an error-weighted average from three experiments. d) Venn diagrams representing transcripts commonly down- and up-regulated (|fold-change| $\geq 2.0, p \leq 0.01$ ) by 1 and HIF-1 $\alpha$ siRNA, by 1 and echinomycin, and by HIF-1 $\alpha$ siRNA and echinomycin. Numbers inside the intersections represent transcripts affected by both treatments. 


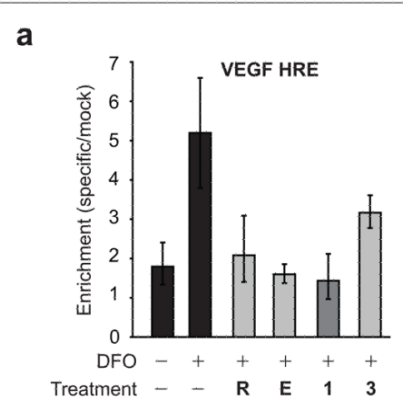

b

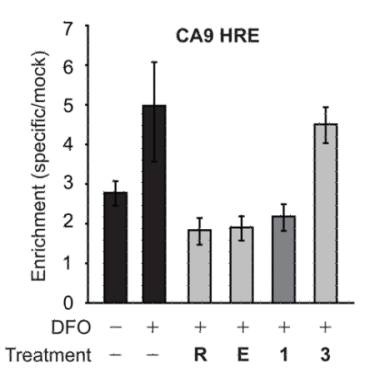

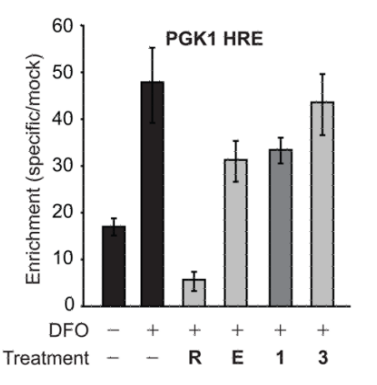

Figure 5.

Chromatin immunoprecipitation at three HREs. a) Chromatin immunoprecipitation of HIF- $1 \alpha$ at the VEGF HRE following DFO treatment: HIF-1 $\alpha$ siRNA, R; echinomycin (100 $\mathrm{nM})$, E; and polyamides 1 and $3(1 \mu \mathrm{M})$. Occupancy is decreased in the presence of R, E, and 1 but only modestly affected by 3 . b) Chromatin immunoprecipitation of HIF- $1 \alpha$ at the CA9 HRE. c) Chromatin immunoprecipitation of HIF-1 $\alpha$ at the PGK1 HRE. 
TABLE 1

Number of transcripts affected $(p \leq 0.01)^{a}$

\begin{tabular}{|lcrrrc|}
\hline & \multicolumn{4}{c|}{ Treatment } \\
\cline { 2 - 5 } & None & R & E & 1 \\
\cline { 2 - 5 } & No DFO & With DFO & With DFO & With DFO \\
\hline Up-regulated (fold change $\geq 2.0$ ) & 662 & 1380 & 3480 & 709 \\
Down-regulated (fold change $\leq-2.0)$ & 1480 & 1810 & 7426 & 1575 \\
Up-regulated (fold change $\geq 4.0$ ) & 62 & 122 & 413 & 57 \\
Down-regulated (fold change $\leq-4.0)$ & 296 & 356 & 4133 & 336 \\
\hline
\end{tabular}

${ }^{a} \mathbf{R}$, HIF-1 $\alpha$ siRNA; E, echinomycin; 1, polyamide. 


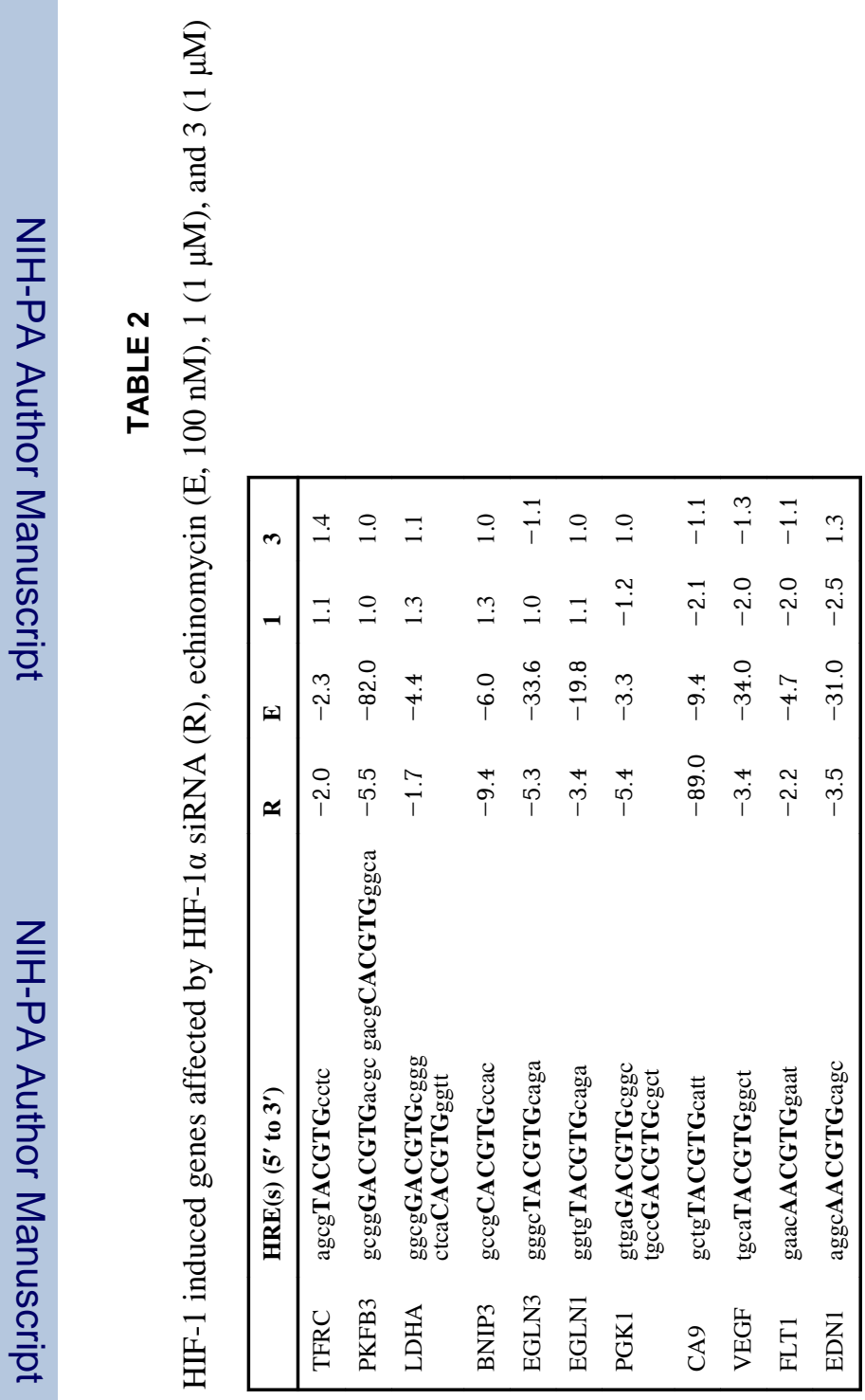

ACS Chem Biol. Author manuscript; available in PMC 2011 March 18. 